\title{
Reframing Learning to Teach Diversity: Multicultural Curriculum within a Cosmopolitan Context
}

\author{
Seungho Moon \\ smoon3@luc.edu
}

Follow this and additional works at: https://ecommons.luc.edu/education_facpubs

Part of the Education Commons

\section{Author Manuscript}

This is a pre-publication author manuscript of the final, published article.

\section{Recommended Citation}

Moon, Seungho. Reframing Learning to Teach Diversity: Multicultural Curriculum within a Cosmopolitan Context. Asia-Pacific Journal of Teacher Education, 45, 5: 469-486, 2017. Retrieved from Loyola eCommons, Education: School of Education Faculty Publications and Other Works, http://dx.doi.org/ 10.1080/1359866X.2016.1245407

This Article is brought to you for free and open access by the Faculty Publications and Other Works by Department at Loyola eCommons. It has been accepted for inclusion in Education: School of Education Faculty Publications and Other Works by an authorized administrator of Loyola eCommons. For more information, please contact ecommons@luc.edu. c) $($ () $\ominus$

This work is licensed under a Creative Commons Attribution-Noncommercial-No Derivative Works 3.0 License. (C) Taylor and Francis, 2017. 


\section{Reframing Learning to Teach Diversity: Multicultural Curriculum within a Cosmopolitan Context}

Seungho Moon

Cosmopolitanism has contributed to extending the scope of diversity, equity, and justice issues beyond the nation-state to a global community. Theorists from multiple disciplines have suggested alternatives for responding to rapidly changing global communities and education. Nussbaum (2002), for example, argues that a person's allegiance and loyalty should not be limited within the nation-state border but should extend to the worldwide community of human beings. Humankind is not limited to a regional space but also functions in a broader context as a world citizenry. Such a sense of belonging to the world community transcends region-based patriotism, providing a strong foundation for cosmopolitan teacher education. A pedagogy inspired by cosmopolitanism encourages preserve and in-service teachers to enlarge the scope of their professional responsibilities throughout the world (Banks, 2013). Major discourses in cosmopolitanism include the pursuit of universalised rights and social justice for cosmopolitan citizens (Nussbaum, 2002), the advancement of cosmopolitan sensitivity (Hansen, 2010; Jupp, 2013), and a rooted cosmopolitanism that balances within and across nation-state borders in order to develop cosmopolitan citizenship (Appiah, 2006). These approaches to cosmopolitanism, whether political, geographic, or cultural in nature, importantly shift discourses about diversity from a local perspective to one framed by the larger global community.

Generally, the aim of conventional cosmopolitan education as a project is to enhance cultural awareness about the self and other, contending that a universalised version of cultural, national identity exists prior to interactions between people in a global community (Banks, 2011; Nussbaum, 2002). For example, Appiah (2006) indicates that empathy and mutual 
understanding occur between cosmopolitan citizens by each party retaining an individual cultural heritage, while simultaneously respecting the "presence of the other" (p. 21). However, I problematise a normalised understanding of conventional cosmopolitanism. I argue that highlighting universal ethics and the Western version of democracy, freedom, and autonomy limits the possibility of examining the multiplicities of cosmopolitan education. If educators do not investigate specific historical, sociocultural, and economic contexts which differ between nation states, then progressing beyond the concept of the "local citizen" to that of the "global citizen" will only perpetuate these universalised ethics at an individual as well as a social level (Miller, 2006; Popkewitz, 2008).

This study investigates a different conceptual, pedagogical approach to teacher education informed by critical cosmopolitanism. Conventional cosmopolitanism aims to cultivate humanity by extending the scope of citizenship from belonging to a local community within national borders to that of a cosmopolitan community operating without borders (Nussbaum, 2002). In contrast, critical cosmopolitanism debunks universalised understandings of cosmopolitanism by highlighting the multiplicity of self-other (Miller, 2006; Todd, 2009), studying the subject's passionate engagement in public spaces (Pinar, 2009), interrogating unpredictable power relations amongst global communities (Hawkins, 2014; Taylor, 2011), and challenging universalised, Eurocentric ethics and practices of cosmopolitanism (Popkewitz, 2008). Delanty (2006) postulates that critical cosmopolitanism occurs "when and whenever new relations between self, other and world develop in moments in openness" (p. 27). This openness in critical cosmopolitanism challenges normative questions in understanding self-other, thereby opening spaces in which to imagine alternatives for translation and construction of new social worlds (Delanty, 2006). Similar to Delanty's challenges of concrete, normalised identities, Todd 
(2009) notes that in critical cosmopolitanism subjectivity is discursively and materially constructed through interactions with others. The self-other relation is linguistically constructed within the proximity of self and other, and cultural categories of race, nationality, or gender do not predetermine subjectivity.

Pedagogically influenced by critical cosmopolitanism, I examine the ways in which preservice and in-service teachers reframe their understanding of diversity within the context of war, globalization, and post-9/11 anxiety. I apply a framework of critical cosmopolitanism to my own pedagogy that underscores the power operations among nation-states, as well as the socio-political interrelationality existing between self and other (Hawkins, 2014; Popkewitz, 2008; Todd, 2009). Among the multiple principles in critical cosmopolitanism, I focus on two major premises of it. First, subjectivity is constructed through reiterating a set of social norms (Butler, 1999). Poststructuralist thinkers, such as Butler (1999, 2009) and Todd (2009), reject the notion of a predetermined, always conscious self. Rather, subjectivity is constructed by interacting with the other, as the consequence of a complicated intersection of race, class, gender, and more (Santoro, 2009). Using this concept of the subjectivity's construction, this study secondly focus on power relations that assign recognition differently depending on the specific socio-political context. In conceptualising power, Foucault (1978) rejects a reified form of sovereign power that contains a node to be captured in order to "emancipate" the oppressed. He argues that power is relational and discursively operates in multiple directions, depending on the specific socio-political context. For example, the notions of cultural difference and sameness are not predetermined but politically constituted. Keeping in mind the Foucauldian notion of power, I ask preservice and in-service teachers to explore power relations in local and global contexts which construct recognition and grief differently between people. 
By reflecting on the learning and teaching that occurred in my course over three academic sessions, I examine how Butler's (2009) theory on recognisability—that is, interrogating the conditions of recognition—-provides a theoretical and pedagogical tool for developing a different approach to teaching diversity. Using the Iraq-U.S. war, Butler (2009) investigates the ways in which modern warfare represents certain lives as more or less important and as more or less worthy of loss and grief. Butler urges her readers to interrogate the operative frameworks "within which certain lives are regarded worthy of protection" while others are not (p. 50).

Butler (2009) does not explicitly indicate her work within the category of cosmopolitanism; however, her emphasis on the investigation of power operations in a global context, as well as the notions of self-other relationships, aligns with the major discourses in critical cosmopolitanism. Critical cosmopolitanism is largely focused on examining power relations among nation states and investigating the self-other relationship in identity construction (Delanty, 2006). Butler's (2009) theory of recognisability creates a new space for discussing the ways in which power circulates during global warfare and thus produces a set of social norms to recognise certain lives as being more important than others. By examining preservice and inservice teachers' active engagement with these topics, I explore the possibility of enriching discourses in critical cosmopolitan teacher education. My central question is to ask how preservice and in-service teachers apply recognisability to cosmopolitanism in their conceptualisation of diversity education. Drawing from Butler's theory, I design coursework and assignments that inspire preservice and in-service teachers to rethink multiculturalism beyond social inclusion and proper cultural responses. The existing outline I am given for the course includes important readings on making diversity and multiculturalism issues part of the school's 
curriculum and encouraging teachers to question their pre-existing assumptions. Adding a global perspective to the course provides a larger context in which to investigate the operating cultural frames. Preservice and in-service teachers investigate different recognition, loss, and grief between human beings by analysing both domestic and international conflicts.

In this paper, I begin with a review of recent literature on diversity issues within the cosmopolitan context. Then, I explicate Butler's theories on recognisability as a theoretical grounding for this paper and explain the context of my teaching and the methodology of my study. In my findings, I articulate two salient themes of (a) analysing the frame of recognition and (b) revisiting the notion of self-other occurring in teaching and learning diversity. Finally, I provide the pedagogical implications of such analysis that might further the advancement of cosmopolitan teacher education.

\section{Critical Cosmopolitanism and Recognisability}

Hawkins (2014) postulates that "much of the literature on cosmopolitanism is silent on issues of difference in privilege, status, and power relations" (p. 107). By fully subscribing to Hawkins's argument, I regard Butler's recognisability as a relevant, crucial theoretical framework in order to enrich cosmopolitanism by interrogating privilege and power relations. I develop a different approach to cosmopolitan teacher education by investigating power operations and self-other relationships in the centre of cosmopolitanism-namely, critical cosmopolitanism.

Butler (2009) indicates frames are the conditions that establish recognisability and grievability of subjects. She challenges readers to consider whose deaths are grievable, "who are worth valuing, whose lives are precarious, and, when lost, are worth public grieving" (p. 125). For example, the deaths of Iraqi citizens are not recognised in the same way (or at all) in the U.S. 
media and public discourse as those of U.S. soldiers. Central to Butler's theory is that statesponsored war and globalisation construct a differential valuing of life and its recognition, which, by definition, is different from recognisability. While recognition is a practice between subjects, recognisability refers to the more general frames that "prepare or shape a subject for recognition" (Butler, 2009, p. 5). Recognition is not pre-given to each living being. As a frame, recognisability proceeds and exceeds recognition and shapes a subject for recognition or nonrecognition. By highlighting the recognisability of a human being, Butler proposes alternative questions in considering multiculturalism. She argues,

The problem is not merely how to include more people within existing norms, but to consider how existing norms allocate recognition differentially. ... The point, however, will be to ask how such norms operate to produce certain subjects as "recognizable" persons and to make others decidedly more difficult to recognize. (Butler, 2009, p. 6) According to Butler (2009), what to put in or outside the frame should not be the major concern in multiculturalism. What matters is to investigate the "frames" themselves to determine the rationale for recognising a subject as grievable or not. Butler's theory on recognisability can inspire preservice and in-service teachers to ponder not only who receives recognition, but also what sets of social norms categorise certain subjects as recognisable or not. Butler's emphasis on a set of social norms originates from the assumption that anyone "is always given over to others, to norms, to social and political organizations" (p. 2).

As a teacher educator advocating global, cosmopolitan issues in teaching diversity, I connect Butler's (2009) concept of recognisability with multicultural teacher education discourses. I highlight power operations in assigning recognition as well as the conditions of recognising a human being as a liveable life. Typically, multicultural teacher education is taught 
in a compartmentalised manner-Week One: Race, Week Two: Gender, Week Three: Class, and so forth. However, I apply Butler's (2009) theoretical and pedagogical foundations in order to generate new questions and contemplations about the meanings of "difference" in cosmopolitan teacher education. I require my preservice and in-service teachers to articulate a diversity curriculum and cosmopolitanism by analysing the ways in which "global interdependency and the interlocking networks of power" operate both locally and globally (Butler, 2009, p. 31).

I challenge preservice and in-service teachers to imagine more complex forms of diversity education that move beyond cultural awareness of others and adding more knowledge about "different" cultures to the curriculum. I instigate my preservice and in-service teachers to explore power relations that circulate in local and global contexts to construct hierarchies of recognition and grief. Why are certain lives valued and treated as more worthy than others? While the predominant discourse about multiculturalism assumes such "already constituted communities, already established subjects" of White/people of colour, man/woman, or rich/poor (Butler, 2009, p. 31), I investigate the possibilities of teaching diversity beyond articulating cultural sameness/difference by using already-determined concepts of self and other. By requiring the teachers to analyse the circulation of power, I encourage them to rethink their habitual ways of understanding diversity grounded in collective binaries of the oppressor and the oppressed. The complexity of cultural difference is related to the question of who is recognised as superior to whom, who assumes the authority to determine such relationships, and how to explore power operations in determining the boundary between us and them (Butler, 2009).

\section{The Study}

I began the conversation on multicultural teacher education by providing qualitative data on using recognisability as a pedagogical approach to advancing cosmopolitanism. I intended to 
contribute to existing cosmopolitan literature by focusing on power operations in comprehending the frames of inclusion/exclusion and self-other relations. Few studies have applied this conceptualisation of critical cosmopolitanism to qualitative research, even though many teacher educators have included cosmopolitanism in teacher education (Hansen, 2010; Reid \& Sriprakash, 2012; Taylor, 2011). This study relied on qualitative data concerning preservice and in-service teachers' learning experiences in diversity issues within the context of cosmopolitanism. I have gathered my research data from a graduate course on diversity issues in curriculum I taught at a public university in the United States. As the school population around this university becomes increasingly diverse, preservice and in-service teachers in my courses wanted to know how to respond to the demographic change. Critical theories and postcolonial studies have addressed historical awareness, power dynamics of cultural differences, and interrelations between local and global communities. I further contribute to the literature on multicultural teacher education by examining the power relations that create the norms of cultural sameness and difference.

Research context. As one of four instructors teaching this course, I was obligated to use shared texts and major topics in my teaching. The traditional outline for the course begins with teaching about the Tulsa Race Riots. This event was recently added to the State public school curriculum, and the members of the university believed, as a premise of diversity education, teachers should know what happened in their region. The course texts included Banks (2013), Sleeter (2005), Wang and Olsen (2009), and important readings in the field of multiculturalism. However, I wanted to expand the existing course in at least two ways: to examine the frames of power operations among local and global conflicts, and to revisit the notions of self-other to enrich discourses in cosmopolitan teacher education. My primary interest focused on 
investigating whether and how the teachers would apply Butler's theory of recognisability to cosmopolitanism in their conceptualization of diversity education. Adding selected chapters ("Introduction" and Chapter 4) from Butler (2009) to the course readings helped me bring these dimensions into focus. I chose the Introduction to cover the major terms of frames, recognisability, and apprehension, as well as to reveal the scope of the book, that is, to interrogate the ways in which state-sponsored warfare represents certain lives as more (or less) worthy of grief and recognition. Of the five chapters, I asked students to read Chapter 4, "NonThinking in the Name of the Normative," because this chapter is bound to Butler's critique of multiculturalism, drawing from local-global interdependency and interwoven networks of power relations.

I introduced the notions of recognisability and grievability throughout the course and asked teachers to consider diversity issues that go beyond promoting cultural awareness and including more "marginalised" groups in mainstream discourses. Because remembering 9/11 happened near the beginning of the semester, I had an opportunity to introduce Butler's examination of U.S. media coverage of the U.S.-Iraq wars after 9/11. This overview of Butler's theory provided opportunities to examine the danger of state-sponsored violence and blind patriotism post 9/11. Furthermore, throughout the semester, Butler's argument for rethinking the frame of constituting "otherness" provided a context for exploring the norms of inclusion and exclusion in discussing diversity. Throughout the course, I reminded the preservice and inservice teachers to attend to the sociocultural conditions that serve as the basis for the recognition of others. They explored the socio-political, economic, and ontological frames through which certain lives are recognised and certain lives fail to be recognised. 
In addition, to bring in the historical dimension, I developed a new assignment, asking the teachers to analyse the Tulsa Race Riots in comparison with racial, religious, or other conflicts outside of the United States. Teachers chose a domestic and international conflict according to their interests, including the Congo war, the Holocaust, and the Kuwait/Iraq War. They explored the historical, socio-political, and cultural backgrounds of the conflicts, including Apartheid in South Africa, Aboriginals in Australia, the Chauri Chaura riot in India, the Uighur and Han riot in China, and the French riots in 2009. In groups of two or three, they analysed local and global issues by examining how media practices influenced recognition of others; that is, they determined the frames that precipitated these conflicts. In the final paper, I asked them to highlight the ways in which they connected global issues to their lives and teaching and to theorise their own perspectives on diversity issues in the curriculum.

Methodology. I used a qualitative research methodology for this paper (Wolcott, 2008). Thirty-four graduate students over the three semesters - 10,13 , and 11 students by semesterfrom a Midwest, suburban, public university in the United States participated in this research. Among the 34 participants were 25 White, two Native American, two Black, and five international students. Most of the participants were White female students, and the seven male students included one Native American, four White, and two Black students. Nineteen participants were preservice teachers, and 15 participants were in-service teachers. The teaching status of each participant is indicated as $P$ for preservice or $I$ for in-service in Table 1. The Institutional Review Board (IRB) of my institution granted ethical approval, and I collected informed consent forms from all participants. 
Table 1

Research Participants

\begin{tabular}{|c|c|c|}
\hline Race/gender & Pseudonyms & Major \\
\hline \multirow[t]{8}{*}{ White female (21) } & Katie $(\mathrm{P})$, Kathy $(\mathrm{P})$, Olivia $(\mathrm{P})$, & Teaching, Learning, \& \\
\hline & Jean $(\mathrm{P})$, Brit $(\mathrm{P})$, Maggie $(\mathrm{P})$, & Leadership (TLL) \\
\hline & Maria (P), Betty (P), Angel (P), & \\
\hline & Donna (I) Marie (I), Renee (I), & \\
\hline & Mead (I), Callie (I), Abby (I), & \\
\hline & Blair (I), Allie (I), Rosa (I), & \\
\hline & Emily (P) & Leisure Studies \\
\hline & Liz (I), Karen (I) & $\mathrm{PhD}$ in Education \\
\hline \multirow{3}{*}{$\begin{array}{l}\text { Asian female (5) } \\
\text { (all international } \\
\text { students) }\end{array}$} & Nova $(\mathrm{P})$, Fila $(\mathrm{P})$, Tina $(\mathrm{P})$ & TLL \\
\hline & Queen (P) & International Studies \\
\hline & Annie (P) & $\mathrm{PhD}$ in Education \\
\hline $\begin{array}{l}\text { Native American } \\
\text { female (1) }\end{array}$ & Andrea (P) & TLL \\
\hline \multirow[t]{2}{*}{ White male (4) } & $\operatorname{Jacob}(\mathrm{I}), \operatorname{Jim}(\mathrm{I})$ & $\mathrm{PhD}$ in Education \\
\hline & Robert (I), Andrew (I) & TLL \\
\hline $\begin{array}{l}\text { Native American } \\
\text { male (1) }\end{array}$ & $\mathrm{KJ}(\mathrm{P})$ & TLL \\
\hline \multirow[t]{2}{*}{ Black male (2) } & Patrick (P), & PhD. in Human Sciences \\
\hline & Jay $(\mathrm{P})$ & TLL \\
\hline
\end{tabular}

I used three sets of data - course discussions, small group presentations, and mid-term and final papers. I have kept the original records, with the exception of face-to-face class discussions. I took notes on these discussions instead of audio or video recordings. A graduate assistant generated field notes by transcribing actual class discussion during the class with her notebook computer. I acknowledged that I may have lost the actual verbal and non-verbal messages I did not grasp during the class by not recording the whole class discussion. However, I attempted to minimise the pressures which the participants may have felt during the class in order to maximise the likelihood that they would actively share their opinions. My research 
journal was also an important data source for recording my observations, questions on teaching the course, and reflections on unexpected events. In addition to my graduate assistant's transcriptions of the class discussion, I wrote brief comments on class interactions during the class. I recorded my thoughts and impressions into a research journal immediately after the class every week.

I analysed the data using open coding, axial coding, and selective coding to generate salient themes (Strauss \& Corbin, 1990). During the open coding, I coded teachers' comments on power, colour blindness, defence of racial identity, cultural awareness, social norms, independent thinking, and recognition. These were the themes that the preservice and in-service teachers used as they conceptualised diversity and multiculturalism. I also grouped similar concepts, including transitions in rethinking self-other, resistance, revisiting diversity education, and self-reflection about local and global conflicts. I then organised the open codes into several major themes relating to moments of transition, teacher educator subjectivity, conceptualisation of cosmopolitanism, and new learning on diversity education. I also compared and contrasted different categories within and among the teachers' transitions to new learning, including insights about the complexity of cultural identity and resistance to racial inequity.

During the selective coding process, I listed examples that illustrated issues and tensions in teaching and learning multiculturalism in the global context. I was careful to rethink any assumptions about proper or effective ways of teaching diversity. I narrated the teachers' engagement and disengagement with diversity issues anchored in Butler's (2009) theory of recognisability. In this study, engagement referred to challenging the teachers' efforts to revisit their existing beliefs informed by readings and class discussions. On the other hand, disengagement indicated the moments they shared strong resistance to rethinking their previous 
views, including the refusal of White privilege and heterosexual understanding of gender in terms of the male/female dichotomy. I categorised four major themes indicating the preservice and in-service teachers' transitions in learning to teach critical cosmopolitanism. These four themes explicate the ways in which preservice and in-service teachers (a) analysed the frame of recognition, (b) asked questions about self-other relationships, (c) connected local and global issues, and (d) imagined new approaches to diversity education. In the findings section, I elaborate two major themes indicating most apparent learning moments gathered from the preservice and inservice teachers' experience: (a) analysing the frame of recognition and (b) revisiting the notion of self-other and its interrelationality. I highlight these two themes in that they are prominent in shifting discourses concerning cosmopolitanism and thus provide implications for advancing critical cosmopolitan teacher education:

\section{Transitions in Learning to Teach Critical Cosmopolitan Curriculum}

As the literature has indicated, developing multiculturalism and diversity education is not a linear process of enlightenment or transformation (e.g., Todd, 2009). As my course progressed, the preservice and in-service teachers discussed local and global tragedies from multiple frames of analysis.

Analysing the frame of recognition. The framework of recognisability prompted two crucial questions: First, why were certain lives and events recognised or not? Second, how did social norms allow such recognitions to operate? Revisiting the Tulsa Race Riots in the United States in comparison to any chosen tragedy or conflict outside the United States provided a tool for advancing multicultural education to move beyond promoting cultural awareness of marginalised groups or more inclusion of such groups into the mainstream. At the beginning of the course, the class examined the Tulsa Race Riots to investigate social injustice occurring in 
the local area. I selected the Tulsa Race Riots not only because of the large scale of violence and the little-known history about it but also because one of our university campuses is the actual site of the riots. In 1921, Tulsa's affluent Black Wall Street, the Greenwood District, was entirely destroyed by the city's White community within 14 hours (Wang \& Olsen, 2009). A large district of 40 square blocks was burned down and entirely destroyed. This destruction was fuelled by the rumour that a White woman, Sarah Page, was raped by a Black man, Dick Rowland. In the ensuing violence, led by an armed White mob and the Ku Klux Klan (KKK), more than 300 Blacks were killed; more than 1,200 homes, schools, churches, and hospitals were burned to the ground; and 7,000 Blacks lost their homes (Christensen, 2012; Franklin \& Ellsworth, 2001). Connecting this local issue of the Tulsa Race Riots with global issues was an important pedagogical strategy to examine the relations of power embedded in different contexts both in the United States and globally. I used Butler's (2009) concept of recognisability in determining a frame of inclusion and exclusion for recognising the importance of historical tragedy. By comparing and contrasting the similarities and differences between the Tulsa Race Riots and a selected global conflict, they examined how power operates to keep perpetuating hegemonic practices, thereby differentiating recognition among populations.

As part of the class activities and assignments, Marie, an in-service teacher, critically investigated the origin and context of the Tulsa Race Riots and the Kuwait-Iraq War while examining power relations among the KKK, White mobs, Tulsa's Black communities, and nation states involved in the Kuwait-Iraq crisis. By placing Butler's recognisability at the centre of her examination, Marie considered social and political analyses of power economics to be of utmost importance in defining and implementing a diversity curriculum in a cosmopolitan context. 
Marie raised a critical question concerning diversity and multicultural issues in curriculum by giving recognition to the "unrecognised" war and riot victims: In what ways did power operate within a specific political and economic context, particularly both in the Greenwood District, a.k.a. "Black Wall Street" and in the Kuwait/Iraq crisis in the 1990s? Whereas reports on the Tulsa Race Riots and the Kuwait/Iraq War have a tendency to portray historical facts concerning who were involved, when it happened, and how it happened, Marie investigated hegemonic practices underpinning the Tulsa Race Riots and the Kuwait/Iraq War. First of all, Marie began her examination of the Tulsa Race Riots with an overarching question: "Where [did] the sense of racial dominance come from and why was it pervasive enough to result in such a senseless tragedy?" Inspired by Butler's ontological question about the "condition" of recognition, Marie investigated the ways in which cultural hegemony played a major part through the Tulsa Race Riots in recognising or not recognising the victim as a grievable, mournful human being. She responded to her previous inquiry question by stating, On the surface, the massacre in Tulsa appears to have been racially motivated. There is no doubt in my mind that the Whites who participated in the looting and burning and death were there because they wanted to exact some sort of revenge on the successful Black community. I believe the message of independent success by Blacks was threatening to the Whites ... Cultural hegemony is unquestionably in play and the goal here is unmistakable: If you want to destroy a culture, destroy their centres of power. Institutions like schools, churches, and the media constantly distribute information to the public, using language to frame their message.

Marie reviewed the cause of the Tulsa Race Riots by exploring the "frame" of the ways in which successful African Americans were viewed in 1921 by White communities supported by the 
presence of the KKK in Tulsa. According to Marie, a set of Eurocentric norms and its worldview were implemented in recognising the White community as being more grievable than the Black community. The Black worldview in the successful Greenwood district was threatened by the White community in that Black worldview did not coincide with the White worldview in the greater Tulsa area, breaking from the status quo of White power and White social domination. Burning property in the Greenwood District including churches, media, and schools was a way to physically cleanse Tulsa of African American influences and stop this progression by destroying the Black community and its values completely.

In her presentation and final paper, Marie connected the Tulsa Race Riots with the Kuwait/Iraq war by concentrating on the economic politics and genocide that happened in both tragedies. By displaying fire and burning images, Marie presented how the KKK, White mobs, and the Iraqi government destroyed Black communities' and Kuwait's cultural heritage and local media in order to maintain and perpetuate historical narratives controlled by Tulsa's White community and the Iraqi government. She reported, "the roiling, greasy black clouds rising from Greenwood were precipitated by White mobs' jealousy [towards the affluent Black community] and their hatred was punctuated by [the] KKK's fire." In a larger context, Marie used the images of fire and bombings which destroyed Kuwait's private and public intellectual propertiesproperties educating cultural and historical heritage via mosques, schools, National Microfiche Archives, and an Arab Times Newspaper Office. The Iraqi government systemically destroyed Kuwait's national archives and local newspapers, and completely “deleted" Kuwait's cultural, historical identity. Furthermore, Marie emphasised dark, toxic clouds of the oil wells set ablaze during the Iraqi's military retreat on February 26, 1991: the dark clouds of smoke and fire represented not only “draining" Kuwait's predominant economic resources but also committing 
the act of "environmental vandalism" that lasted for more than seven months. Marie evaluated the factors behind and consequences of these local and global conflicts:

My study of the Iraqi invasion of Kuwait in 1990 offered an entirely different, and yet eerily similar study of power and control. The systematic obliteration of the Kuwaiti national identity by the Iraqi occupying forces was sickeningly reminiscent of the burning of Greenwood in Tulsa. The more I researched the Iraqi occupation of Kuwait, the more I realized that meaningful discussions of cultural identity and diversity education could not happen without discussion of power economics. In both [conflicts], the aggressor gained power by methodically destroying the identity of the oppressed group, leading to more complex problems of conflict.

Marie argued that both the Kuwait/Iraq and Tulsa conflicts are ever-changing phenomena dependent on the economic, cultural, and political interests among multiple groups and assigning different recognition and grief among populations. She analysed power relations that operated both during the Tulsa Race Riots and the Kuwait-Iraq crisis by reflecting on Butler's (2009) ontological question, "whose lives are considered valuable, whose lives are mourned, and whose lives are considered ungrievable” (p. 38). Tulsa's Black community victims and Kuwaiti citizens were lost and destroyed. According to Butler's argument, however, nothing was destroyed because their lives were not recognised as grievable lives even before the conflict occurred. Each victim represented an ungrievable life that "cannot be mourned because it has never lived, that is, it has never counted as a life at all" (p. 38). By politicising local and global conflicts using the frame of recognition and grief, Marie articulated that the desire for power and control produced cultural hegemony. Such cultural hegemony perpetuated a hierarchical norm to recognise a certain group of people's lives as being more worthy of mourning than the lives of others, as 
indicated in blocking local and international media's access to the crises, the victims of White mobs' looting and burning of the Greenwood District, and unresolved reparations to the families of missing persons and properties in Tulsa and Kuwait.

Another small group conducted a project on the Chauri Chaura Riots in India in 1922. Liz, Annie, and Jacob examined riots outside the United States that happened close to the same time as the Tulsa Race Riots. The peasants in Chauri Chaura had joined the Non-Cooperation Movement to dismantle British colonial rule of India. This group explored the framework of power relations applied to the unrelated groups in Tulsa and Chauri Chaura, which help to analyse the events in both instances. During the presentation, Liz stated,

Both citizens requested their governments to provide equal rights and protection to the citizens not a part of the governing group. In both cases the governments failed to give recognition to the people who were demanding liberation. In India's case, villagers were assembling under the direction of the Non-Cooperation Movement to protest the price of meat at the town bazaar when [the police subdued them]. In the case of the Tulsa Race riot, [Black community implored] to prevent a lynching of Dicky Rowland and [opposed] keeping authority in the hands of the dominant White race.

Liz, Annie, and Jacob stressed the segregated frame of reference that gave rise to lynching and justified violence. The major local newspapers in Tulsa at the time reported the riots with inflammatory headlines, such as "Two Whites Dead in Race Riot"; "Arrest of Young Negro on Statutory Charge Caused Battle between Races"(June 1st, 1921, The Tulsa World). "Media blackouts" across the Tulsa Race Riots and Chauri Chaura occurred when the media supported and perpetuated state-sponsored violence through an attitude of patriotic solidarity (Zembylas \& Boler, 2002, para 1). By “distorting” the frame for recognising all people's voices, the media 
blackouts created a frame for recognising the police, White mobs, and British colonisers as more valuable than the victims of the riots in these tragedies.

Liz, Annie, and Jacob emphasised the opportunism related to the Tulsa Race Riots to uphold and increase existing racial tensions and destroy the affluent Black community. Notably, in comparing power relations between the Tulsa Race Riots and Chauri Chaura, they highlight ed the ways in which a set of social norms operated, whether with Indian peasants or African Americans. Poor Indian peasants' and African Americans' rejection of an existing social order made the state-sponsored violence valid in the eyes of the press and justified a violent response to their attempts for liberation and justice.

Referring to Butler's (2009) recognisability, Liz, Annie, and Jacob noted that recognisability precedes recognition. That is, recognition or grief occurs only if the person lost is regarded as a recognisable or grievable human being. Particularly, Annie emphasised the ways in which Black Tulsans' and Chauri Chaura Indians' lives were not recognised historically and were thus "ungrieved." By refusing recognisability for the Indian peasants during the Colonial Era, Britain removed the very prerequisite for proper recognition of them as valuable human beings.

Connecting the Tulsa Race Riots with global conflicts became meaningful when preservice and in-service teachers analysed the "asymmetries of power" (Butler, 2009, p. 358) that generated unequal treatment and different recognition among people. Within multiple interpretations of the Tulsa Race Riots and global conflicts, such as the Kuwait/Iraq War and Chauri Chaura Riots, preservice and in-service teachers explored the "frames" in place for assigning different recognition. Butler (2009) articulated, “[T]here are 'lives' that are not quite—or, indeed, are never—recognized as lives" (p. 4). By adopting Butler's articulation of 
frames, the preservice and in-service teachers revisited the ontological questions of who is recognised as superior to whom, who determines such superiority, and what frame is used to decide the boundary of "us-them."

Revisiting the notion of self-other and its interrelationality. Throughout the semester, I encouraged the preservice and in-service teachers to rethink the notion of cultural identity that they used to take it for granted, such as being a White, working class, female teacher living in a rural area. I attempted to provide multiple frames to examine their cultural identity moving beyond collective identities of race, gender, class, and so on. My hope was that preservice and in-service teachers would transition from promoting cultural awareness, to asking questions concerning the point at which decisions about self-other "emerge as a relevant, appropriate, or obligatory act” (Butler, 2009, p. 20). Thus, I facilitated the preservice and in-service teachers to review the frame of recognition in articulating the notions of self-other and us-them. Rather than discovering shared, collective components of race/ethnicity, gender, and class identity, they probed the very frames or norms of recognising a person as one of "them" or one of "us."

As the discussion began about the Tulsa Race Riots, many of the teachers focused on understanding the tragedy through the White-Black dichotomy and associating their own racial/ethnic identities with the historical and political conflicts. Similar to research findings in White teacher identity, the preservice and in-service teachers in my courses showed resistance, guilt, and fear discussing the subject in-depth (Matias, Viesca, Garrison-Wade, Tandon, \& Galindo, 2014). I have observed that the preservice and in-service teachers' dichotomous understanding of self-other or us-them prevented a more constructive discussion about the tragedy, responsibility, and power operating during the riots. I considered resistance as a teaching moment to address the frames of perpetuating White privilege and the power operation 
dividing us and them. I applied a pedagogical approach to address the racialised nature of the historical events and its persisting impact in our current racialised society. Multicultural educators have suggested numerous ways to address such racial inequity for preservice and inservice teachers. Leonardo (2004), for example, suggested rigorously examining White racial domination, as well as critically investigating "the conditions of white supremacy [making] white privilege" (p. 350). As a pedagogical strategy to deal with such resistance, I implemented Butler's (2009) ontological and epistemological question about the role of the frame of recognition in including a person as "us" and excluding the other person as "them."

During the course, preservice and in-service teachers analysed the Tulsa Race Riots and global conflicts through a "divided" version of collective identity categories, including race, gender, class, religion, and nationality. When these teachers again began to avoid discussing White privilege or reiterating meritocracy logic due to the past economic hardship, I asked follow-up questions from a different frame to review the power operation behind recognition. For example, as mentioned, the class began blaming the White community for the Tulsa Race Riots and discussing their social responsibility. Some of the White teachers were extremely upset and explicitly voice their uncomfortable feelings:

Donna: No, all White people have privilege — that's not true! Because as a woman, I have encountered prejudice on more than one occasion. You learn to pick up and walk on and go.

Instructor: Sexism exists everywhere. In that sense, women are trying to make their voice heard. But Butler proposes a different version of questions: Why do we value men's knowledge as more important than that of women? She invites us to ask about the conditions of recognition rather than highlighting more inclusion of different voices. 
While recognising Donna's lived experience due to her socio-economic status (SES) and gender, I did not underestimate unfair treatment for the poor and women in a patriarchal society. Yet, I hoped to redirect the discussion from debating who suffers the most to cautiously examining social inequity and responsibility. I raised the question of "What is the frame for making decisions regarding recognition?” I reminded Donna of Butler's (2009) question: “Under what conditions does precarious life acquire a right to protection, and under what conditions does [it] not?” (p. 20). During the class discussion, Donna did not directly respond to my question regarding recognisability. However, another student, Allie, articulated the problem of stable, collective identity by stating, "I identify as a woman, but that doesn't mean all women have the same issues I do. Seeing identity as fluid and discursively dependent on the actions and inaction of others changes the framework of multiculturalism." Allie indicated the complexity of identity and underscored the importance of shifting identity questions from "what" cultural differences exist, to "how" to minimise stereotypical images about the other. She understood the importance of critical examination about self-other. That is, discourses in multiculturalism are enriched by interrogating how power dynamics operate and, thus, discursively construct self-other relationships.

In her qualitative study, Santoro (2009) has emphasised the importance of understanding self in conjunction with knowledge of the other. She argues that the divided understanding of self-other without considering connectivity reproduces a stereotypical image about the other and imposes a cultural deficit model onto students of colour. Subscribing to Santoro's argument, I postulate that reducing subjectivity to group-based essentialism is irresponsible and even unethical because such educational practice results in another version of exclusion by not recognising people who do not follow the norms. Allie's new understanding of self-other 
aligned with Santoro's argument in creating a different approach to multiculturalism to minimise any normalised understanding about self-other. No self exists before actual interactions with the other, and such political interactions mark the beginning of understanding cultural sameness and differences (Todd, 2009). Espousing a new approach to self-other provides an opportunity to address any universalised understanding of culture that reinforces stereotypical images about the other, even when the motivation is politically driven.

Investigating the power relations in the self-other relationships enriched the discussion about social inequity and recurring global tragedies. By the end of the semester, some of the preservice teachers shared their new understandings about self and other, reflecting on their projects comparing the Tulsa Race Riots and global conflicts. Patrick's project about the Congo War and his group's analysis were salient to challenging the binaries of Black-White in understanding the cause and effect of the conflict:

Due to my personal framework [as a person of colour], I feel strongly about who is right and who is wrong when evaluating the Tulsa incidents because I can identify with the people of Greenwood. I am less able to identify with either group in the Congo conflict because I feel no direct connection to the people and my usual framework of race cannot be applied...[D]uring the Congo war, the group that would be traditionally considered in the right is now in the wrong...[T]hings cannot be seen in such black and white terms such as right and wrong. Instead a systemic approach must be applied in order to identify the true mechanisms that allow for these types of incidents to occur.

Patrick challenged his understanding of self-other by rethinking any stable meaning of what it meant to be a "Black" male in a global context. Patrick's sense of belonging to one cultural group was challenged in comparing the different socio-political contexts of the United States and 
the Congo. He began to consider political and sociocultural effects in defining who he is and where he belongs, rather than predominantly relying on a collective Black-White paradigm. Additionally, Patrick recognised the potential danger of collective identity when a solidarity produces another hegemonic power over the other group as seen in the Congo conflict. In defining multicultural education, Patrick states,

My definition of multicultural education was only based in my experiences and the majority of my experiences surround the issue of race. It was at this point that I began to feel that you can't define multicultural education because it would only be true within the frame [in] which you are living.

Patrick's epiphany about his identity was particularly meaningful because he learned to unlearn his existing beliefs about self and other politically situated within both local and global contexts. Patrick's narratives indicated the importance of critical investigation of subjectivity by examining a socio-political context in constructing self-other.

In theorising self-other, Todd (2009) has postulated stable subjectivity does not exist before subjects interact with each other; instead, the notion of self-other is linguistically and materially constructed by the actual interaction between self and other, where power operates through discursive practices. This examination of self-other relationality through political interaction provides the frame for studying the division between us and them. The preservice and in-service teachers raised questions about the ways in which identity is socially and discursively constructed, rather than discovering a collective, stable self. Patrick, most notably, developed his new understanding about diversity and equity by reviewing the discursively constructed notion of self-other, which is contextualised by a specific political context. This approach to identity provided more opportunities to examine the complexity of multiculturalism that cannot be 
limited to promoting cultural awareness or including more voices from "marginalised groups" in the existing norms.

\section{Discussion and Implications: Toward critical cosmopolitan teacher education.}

Critical cosmopolitanism raises provocative questions and provides an important theoretical and pedagogical tool for teacher educators to extend the current discourse in diversity education. In this paper, I argue for the potential to enrich diversity education by applying a new frame to study the cause and effect of recurring local and global conflicts. As an advocate of global mindedness in teacher education, I constantly ask my preservice and in-service teachers to examine the circulating conditions of recognition and self-other interrelationality in constructing the concepts of "us" versus "them." The significance of critical cosmopolitan teacher education lies in developing new approaches to teaching diversity. I discuss two major points in imagining and theorising critical cosmopolitan teacher education: the significance of examining power in local and global communities and the importance of the interrelationality of self-other. Teacher educators around the world are eager to learn new pedagogical strategies for teaching diversity (Ferguson-Patrick, Macqueen, \& Reynolds, 2014). Although my suggestions are based on a local context of the United States, they may be translatable for use in other nation states.

Exploring power operation as the centre of discourse. A critical examination of power relations in the cosmopolitan community advances multicultural teacher education. Goodwin (2010) requests that teacher educators prepare sociologically sensitive and socially knowledgeable teachers, in addition to increasing personal knowledge and pedagogical knowledge within the global context. Using Butler's (2009) ontological question-when and under what circumstances is life grievable - encourages preservice and in-service teachers to analyse power relations and social norms both locally and globally. Additionally, examining the 
frames of recognition through which others are perceived opens the possibility of seeing current tragedies through historical perspectives. In 2014, the United States mourned the brutal death of Michael Brown and other incidents related to "White" police officers shooting unarmed "Black" citizens. More scepticism about racial justice in a supposedly post-racial society was provoked by the Grand Jury's decision not to indict the White police officer responsible for Brown's death. In this context, how can teacher educators revisit previous tragedies, such as the beating of Rodney King and ensuing riots in 1992? What are the similarities and differences between the Tulsa Race Riots of 1921 and acts of racism which recur both locally and globally? Further, how can we be sensitive to unrecognised hate crimes in a time of "media blackouts" (Zembylas \& Boler, 2002, para 1)? Butler's (2009) ontological question about precariousness and recognisability of life has the potential to engage preservice and in-service teachers in examining contemporary inequity issues in their own communities. The framework of recognisability is applicable as a meaningful pedagogical tool, not only for considering the conditions of recognition, but also for addressing current inequities in education and society. I suggest teacher educators consider applying Butler's (2009) recognisability of life as an important pedagogical approach to teaching diversity. Preservice and in-service teachers can then examine the conditions of recognition as liveable life, rather than merely focusing on what works best for increasing teachers' global cosmopolitan awareness.

Investigating self-other interrelationality. Critical cosmopolitan teacher education facilitates multiple teaching practices by emphasising the interrelationalities of self-other. This approach does not translate to ignoring the historical, collective wounds that have happened to specific groups. Rather, it is a call to pay attention to the way self-other is socio-politically constructed within a very specific context. In the middle of global conflicts, patriotic solidarity 
usually destroys other citizens. Butler (2009) challenges fixed communities, already established subjects, and the frames of recognition and grief by offering a different lens for thinking about the collective "we." Butler offers an openness to discussions about self, other, and the worldan openness that is also a foundation of multiculturalism and challenges the tyranny of solidarity seen in the context of the U.S.-Iraq war - the sense of belonging to a certain group that reproduces exclusionary norms of recognisability.

Overall, Butler's (2009) question of when life is grievable and recognisable provides a crucial theoretical, pedagogical framework for teacher educators to teach diversity differently in a cosmopolitan context. Cosmopolitan teacher education should always extend knowledge beyond increasing global cultural knowledge and understanding self-other in a collective unit of race/ethnicity, class, gender, and nationality. Teacher education programmes will benefit from applying critical cosmopolitanism in motivating teachers to ponder carefully what they are expected to teach and who determines these expectations. Thus, critical cosmopolitanism in teacher education encompasses openness toward cultural identities by investigating socially and discursively constituted notions of self-other (Delanty, 2006). Preservice and in-service teachers may be provided with more opportunities to answer the fundamental curriculum questions: who we are, what to teach, and who decides curriculum. These questions promote diversity in teacher education by imagining different approaches to investigating cultural sameness/difference in the cosmopolitan context. 


\section{References}

Appiah, K. A. (2006). Cosmopolitanism: Ethics in a world of strangers. New York, NY: Norton.

Banks, J. A. (2011). Educating citizens in diverse societies. Intercultural Education, 22(4), 243251.

Banks, J. A. (2013). An introduction to multicultural education (5th ed.). Boston, MA: Allyn \& Bacon.

Butler, J. (1999). Gender trouble: Feminism and the subversion of identity (10th anniversary ed.). New York, NY: Routledge.

Butler, J. (2009). Frames of war: When is life grievable? Brooklyn, NY: Verso.

Christensen, L. (2012). Burned out of homes and history: Unearthing the silenced voices of the Tulsa Race Riot. Rethinking Schools, 27, 12-18.

Delanty, G. (2006). The cosmopolitan imagination: Critical cosmopolitanism and social theory. British Journal of Sociology, 57(1), 25-47. doi:10.1111/j.1468-4446.2006.00092.x

Ferguson-Patrick, K. F., Macqueen, S., \& Reynolds, R. (2014). Pre-service teacher perspectives on the importance of global education: World and class views. Teachers and Teaching: Theory and Practice. 20, 470-482.

Foucault, M. (1978). The history of sexuality, Vol. 1: An introduction (R. Hurley, Trans.). London, UK: Penguin Books.

Franklin, J. H., \& Ellsworth, S. (2001). History knows no fences: An overview. In Tulsa Race Riot: A report by the Oklahoma Commission to Study the Tulsa Race Riot of 1921 (pp. 21-35). Retrieved from http://www.okhistory.org/research/forms/freport.pdf

Goodwin, A. L. (2010). Globalisation and the preparation of quality teachers: Rethinking knowledge domains for teaching. Teaching Education, 21, 19-32. 
Hansen, D. T. (2010). Cosmopolitanism and education: A view from the ground. Teachers College Record, 112, 1-30.

Hawkins, M. R. (2014). Ontologies of place, creative meaning making and critical cosmopolitan education. Curriculum Inquiry, 44, 90-112.

Jupp, J. C. (2013). Undoing double binds in curriculum: On cosmopolitan sensibilities in US curriculum studies. Journal of American Association for the Advancement of Curriculum Studies, 9, 1-19. Retrieved from http://www.uwstout.edu/soe/jaaacs/upload/v9_Jupp.pdf

Leonardo, Z. (2004). The color of supremacy: Beyond the discourse of "White privilege." Educational Philosophy and Theory, 36, 137-152. Retrieved from http://doi.org/ 10.1111/j.1469-5812.2004.00057.x

Matias, C. E., Viesca, K. M., Garrison-Wade, D. F., Tandon, M., \& Galindo, R. (2014). "What is critical Whiteness doing in our nice field like critical race theory?” Applying CRT and CWS to understand the White imaginations of White teacher candidates. Equity \& Excellence in Education, 47, 289-304. Retrieved from http://doi.org/10.1080/ 10665684.2014 .933692

Miller, J. L. (2006). Curriculum studies and transnational flows and mobilities: Feminist autobiographical perspectives. Transnational Curriculum Inquiry, 3, 31-50. Retrieved from http://nitinat.library.ubc.ca/ojs/index.php/tci

Nussbaum, M. (2002). Education for citizenship in an era of global connection. Studies in Philosophy and Education, 21, 289-303.

Pinar. W. F. (2009). The worldliness of a cosmopolitan education: Passionate lives in public service. New York: Routledge. 
Popkewitz, T. (2008). Cosmopolitanism and the age of school reform: Science, education and making society by making the child. New York, NY: Routledge.

Reid, C., \& Sriprakash, A. (2012). The possibility of cosmopolitan learning: Reflecting on future directions for diversity teacher education in Australia. Asia-Pacific Journal of Teacher Education. 40, 15-29.

Santoro, N. (2009). Teaching in culturally diverse contexts: What knowledge about "self” and “others" do teachers need? Journal of Education for Teaching, 35, 33-45. Retrieved from http://doi.org/10.1080/02607470802587111

Sleeter, C. E. (2005). Un-standardizing curriculum. New York, NY: Teachers College Press.

Strauss, A., \& Corbin, J. (1990). Basics of qualitative research: Techniques and procedures for developing grounded theory. Thousand Oaks, CA: Sage.

Taylor, L. (2011). Feeling in crisis: Vicissitudes of response in experiments with global justice education, Journal of the Canadian Association for Curriculum Studies, 9, 6-65.

Todd, S. (2009). Toward an imperfect education: Facing humanity, rethinking cosmopolitanism. Boulder, CO: Paradigm.

Wolcott, H. F. (2008). Writing up qualitative research (3rd ed.). Thousand Oaks, CA: Sage.

Wang, H., \& Olson, N. (Eds.). (2009). A journey to unlearn and learn in multicultural education. New York, NY: Lang.

Zembylas, M., \& Boler, M. (2002). On the spirit of patriotism: Challenges of a "pedagogy of discomfort." Teachers College Record, 104(5). Retrieved from http://www.tcrecord.org/ content.asp? contentid $=11007$ 